\author{
Review Article \\ www.ijrap.net (ISSN:2229-3566)
}

\title{
PHYSIOLOGICAL EVALUATION OF AHARA PARINAMA KARA BHAVA: A REVIEW
}

Anju Aravind T ${ }^{1 *}$, Pradeep K ${ }^{2}$, Anjali Sivaram ${ }^{3}$

${ }^{1}$ PG Scholar, Department of Kriya Shareera, Government Ayurveda College, Kannur, Kerala, India

${ }^{2}$ Associate Professor, Department of Kriya Shareera, Government Ayurveda College, Tripunithura, Kerala, India

${ }^{3}$ Associate Professor, Government Ayurveda College, Kannur, Kerala, India

Received on: 03/03/20 Accepted on: 15/04/20

\begin{abstract}
*Corresponding author
E-mail: anjuthapasya@gmail.com
\end{abstract}

DOI: 10.7897/2277-4343.110367

\begin{abstract}
Ahara is one of the most important factors of life. It is the main reason for strength, complexion and vitality. The human body is the product of ahara, even so diseases arise on account of unwholesome food. The ingested food provides growth and strength to the body after digestion, metabolism and assimilation. Ayurveda describes the factors under the heading Ahara Parinama Kara Bhava. The six factors, when remaining in balanced stage, the digestion takes place properly. Out of these six factors only Agni is directly involved in digestion and the others are helping factors only.
\end{abstract}

Keywords: Ahara, Agni, digestion

\section{INTRODUCTION}

The Dravyas which are chewed and swallowed into the stomach through the esophagus are called Ahara. It is the most important factor for sustenance of life. Ahara is one among the trayopastambhas ${ }^{1}$ (Three pillars of life) and plays an important role in prevention of disease as well as promotion of health.

Ayurveda describes four forms of food namely asita (eatables), khadita (chewable), peeta (drinkable) and leeta (lickable ${ }^{2}$ ). Ahara is considered as Mahabhiashajya and gunayukta ahara helps to prevent lifestyle diseases.

\section{Ahara Parinama Kara Bhavas}

Ahara is that when substance consumed, which on their vipakva nourishes their respective gunas of Pancha mahabhuta in the body. Parinama means the process of digestion and metabolism of ingested food. Bhava means the factors present inside the body. Thus, Ahara Parinama Kara bhavas ${ }^{3}$ are the factors present in the Shareera which are responsible for the digestion and metabolism of ingested food. They are six in number.

\section{Ushma}

"Ushma pachati"

The factors which are particularly responsible for digestion of ingested Ahara are ushma. Here ushma is pachaka pitta or Agni which supports and nourishes seven dhatwagnis and five bhootagnis. Pachaka pitta is present in between amasaya and pakvasaya. Despite its panchabhoutika nature, it is dominated by tejas bhuta and devoid of the qualities of ap bhuta (tyakta dravatva). Thus, with the help of vayu and kleda, it attends to the functions such as dahana and pachana. So obtains the name Agni. It also separates Sara and Kitta.
As it is the factor particularly responsible for digestion; it can be correlated with

- Digestive enzymes

- $\mathrm{pH}$ required for proper activation and functioning of enzymes

- Basic temperature

- GI hormones involved in digestion

Digestive enzymes include salivary enzymes, gastric enzymes, pancreatic enzymes and brush border enzymes of the small intestine. Salivary juice contains salivary amylase, maltase and lingual lipase. Gastric juice contains mainly proteolytic enzymes like pepsin; rennin etc. Gastric juice is highly acidic with $\mathrm{pH}$ of 0.9 to 1.2 and is due to the presence of hydrochloric acid. Pancreatic juice is highly alkaline, and it contains proteolytic enzymes like trypsin, chymotrypsin. It also contains Lipolytic enzymes like pancreatic lipase etc. Secretions from the small intestine are known as succus entericus. It is alkaline and contains Proteolytic, amylolytic and Lipolytic enzymes. Bile contains bile salts and bicarbonates which help in the digestion and absorption of fats.

Vayu

"Vayurapakarsheti"

According to Chakrapani, apakarshana is stimulation of Agni and to bring down the food near Agni. Anna praveshadi Kriya is the function of Prana vayu ${ }^{4}$. Prana vayu brings down the food into amasaya i.e. site of pachaka pitta. According to Chakrapani, it maintains food in different parts of mahasrotas for specific time required. Samana vata is situated near to antaragni and attends to functions such as retaining of food (annadharana), digestion (pachana), separation of essence and wastes (vivechana) and moving the waste products downwards (kitta adho nayanadhikriya ${ }^{5}$ ) 
Vyana vata attends the functions such as annaswadana (feeling of tastes of food), separating waste and nutrient portions of the food and supplying nourishment to all the Dhatus in proper order ${ }^{6}$. Apana vata located in the Apana Desha, attends to functions such as elimination of vit $^{7}$ etc.

Apakarshana in the context of digestion can be correlated with

- The process of deglutition,

- Movements of GIT, and

- Nervous stimulation of digestive juices.

Deglutition $^{8}$ or swallowing refers to passage of food from the oral cavity into the stomach. It occurs in three stages. Though beginning of deglutition is a voluntary act, later it becomes involuntary and is carried out by a reflex action called deglutition reflex.

Gastric motility can be described as

Motility of the empty stomach, which includes:

- Migrating motor complex, and

- Hunger contractions.

Gastric motility related to food, includes

- Receptive relaxation,

- Mixing peristaltic waves, and

- Gastric emptying

Motility of small intestine ${ }^{9}$ can be described as

Motility during inter digestive period, which includes:

- Migrating motor complexes

- Motility during digestive period

- Mixing movements such as segmentation contractions and pendular movements,

- Propulsive movements such as peristaltic contractions and peristaltic rush, and

- Movements of villi.

Motility reflexes, which comprises

- Peristaltic reflex

- Gastroileal reflex, and

- Intestinointesinal reflex.

The movements of colon are

- Haustral shutting,

- Peristalsis, and

- Mass movements.

Vata also stimulates Agni in order to digest food. Regulation of salivary secretion regulated only by nervous mechanisms. ANS is involved in the regulation of salivary secretion.

Gastric secretion has three phases of secretion. They are

- Cephalic (only nervous)

- Gastric phase (nervous hormonal)

- Intestinal phase (mostly hormonal)

Regulation of pancreatic secretion is regulated by both nervous and hormonal factors. Pancreatic juice is
- Cephalic phase (nervous)

- Gastric phase (hormonal)

- Intestinal (hormonal)

Bile secretion is a continuous process though the amount is less during fasting. Secretion of bile from the liver and its release from GB are influenced by some chemical factors. Secretion of brush border enzymes is regulated by both hormonal and nervous factors.

Hormone gastrin is secreted by $\mathrm{G}$ cells of the stomach and it stimulates gastric glands to secrete gastric juice with more pepsin and hydrochloric acid and also it accelerates gastric motility. Substance P increases the mixing and propulsive movements of the small intestine. Cholecystokinin is produced by I cells of duodenum and jejunum and it contracts gall bladder and stimulates exocrine pancreatic secretion. Vasoactive intestinal polypeptide stimulates secretion of the small intestine and relaxes smooth muscles of intestine.

Functions of myenteric ${ }^{10}$ plexus are

- Control of motility of gut

- Inhibition of pyloric sphincter

- Inhibition of ileocaecal valve

Meissner's plexus controls the secretory activity and blood flow to the gut.

\section{Kleda}

"Kleda shaithilyam apadayati"

Kleda loosens the ingested food. Kleda is a Kaphaja Bhava. Kledaka kapha present in the amasaya moistens the solid food hence the name Kledaka kapha. Bodhaka kapha is present in the tongue and helps in the appreciation of taste. Bodhaka kapha present in the jihwa is responsible for the perception of taste, so it can be correlated with mucus and serous secretion of salivary glands. Kledaka kapha in the amasaya provides ardrata to ingested food which can be taken as gastric serous secretion.

When the food is taken into mouth, it is moistened and dissolved by saliva. Mucus membrane of the mouth is also moistened by saliva. Mucin of saliva lubricates the bolus and facilitates swallowing ${ }^{11}$. By the solvent action of saliva, it dissolves the solid food substances so that the dissolved substances can stimulate the taste buds. The stimulated taste buds recognize the taste. Chemical digestion, through a process called hydrolysis, uses water and digestive enzymes to break down the complex molecules. For example, the basic building blocks of proteins are amino acids. The bonds that hold amino acids together are peptide bonds. To break the peptide bonds in a protein, a hydrolysis reaction is needed and enzymes like proteases are needed to break up the protein. So this hydrolysis reaction can be considered as kleda to some extent.

Gastric juice contains insoluble and soluble types of mucus. The insoluble mucus is such a viscid that it forms a gel-like coat over the mucosa. The intestinal juice contains mucus, which is secreted by Brunner's gland and goblet cells. Mucus secretion serves a protective role preventing $\mathrm{HCL}$ and chyme from damaging the duodenal mucosa.

Water content of digestive juice is,

- Gastric juice - $99.45 \%$ 
- Pancreatic juice - $99.5 \%$

- Liver bile - $97.5 \%$

- Succus entericus - $99.5 \%$

\section{Sneha}

"Sneham mardavam janayati"

Sneha softens or lubricates the ingested masticated food or the bolus. Sneha can be the sneha amsa of food taken i.e. oils or fatty part of diet. Sneha can ignite unignited Agni; snigdhamsa of the body; which maintains the moistness of the body and helps for malasanga naasa. Ingestion of fats specially stimulates contraction of gall bladder to produce bile which supports that sneha ignites Agni.

Bile salts are required for the digestion and absorption of fats in the intestine. Lipolytic enzymes of GIT cannot digest the fats directly because the fats are insoluble in water due to surface tension. Emulsification is the process by which the fat globules are broken down into minute droplets made in the form of milky fluid by the action of bile salts. Bile salts help in the absorption of digested fats from the intestine into blood. Bile salts combine with fats and make complexes of fats called micelles. The fats in the form of micelle can be absorbed easily.

\section{Kala}

"Kala paryaptamabhinivartayati"

"Kale pakvam samam samyak pachatyaayurvivardhaye"

Paryaptam means sufficient. Abhinivarthayati means change or transformation. Food is sufficiently transformed into absorbable nutritive form. Here kala refers to two meanings. Kala is time taken for complete digestion of food. The proper digestive process completes in a required time. Food resides in every part of GIT for a particular time so that digestive juices can act properly, and absorption of digested food will take place. The time taken for digestion is kala.

Kala is the time at which hunger arises. If food is taken at time of hunger, then it is digested properly due to proper nervous stimulation of digestive juices. Gastric emptying is the process by which the chyme from the stomach is emptied into the intestine. Food that is swallowed enters the stomach and remains there for about 3 hours. During this period digestion takes place. Enterogastric reflex inhibits gastric emptying and is elicited in the presence of chyme in the duodenum, which prevents the further emptying of stomach.

Gastrocolic reflex refers to contraction of the colon induced by entry of food into the stomach. This reflex results in an urge to defecate after a meal.

Food enters in ileum -8 hours after meal

Caecum and ascending colon- 13- 17 hours after meal

Sigmoid colon- 18 hours after meal

Rectum - 24 hours after meal; this is followed by defecation

There is a specific transit time of chyme in all parts of GIT, which is very important for proper functioning of the digestive system.

\section{Samayoga}

Sama means proper. Yoga means collection. Hence Samayoga means proper collection or wholesomeness of food. Chakrapani explains the meaning of Samayoga by ashtaharavidhi viseshayatana which includes nature of food, processing of food, combination of food stuff, quantity of Ahara, habitat, season, rules and regulations for taking food and the person who consumes food.

\section{CONCLUSION}

If each and every element of Ahara Parinama Kara Bhava is in its suitable form, then the food ingested will be properly digested and metabolized then only there will be samyavastha of Shareera.

\section{REFERENCES}

1. Prof. KR. Srikanta Murthy. Ashtanga Sangraha of Vagbhata. Virudhanna vijnaniya. 9th ed. Varanasi: Chaukhambha Orientalia; 2005. p. 203.

2. RK. Sharma, Bhagwan Dash. Charaka Samhita. Trividha kukshiyam. Varanasi. Chaukhambha Sanskrit series office; reprint; 2015. p. 139.

3. RK Sharma, Bhagwan Dash. Charaka Samhita. Shareera vichayam. Varanasi. Chaukhambha Sanskrit series office; reprint; 2015. p. 437.

4. Prof. KR Srikanta Murthy. Ashtanga Sangraha of Vagbhata. Doshabhediyam. 9th ed. Varanasi. Chaukhambha Orientalia; 2005. p. 368.

5. Prof. KR Srikanta Murthy. Ashtanga Sangraha of Vagbhata. Doshabhediyam. 9th ed. Varanasi. Chaukhambha Orientalia; 2005. p. 368.

6. Prof. KR Srikanta Murthy. Ashtanga Sangraha of Vagbhata. Doshabhediyam. 9th ed. Varanasi. Chaukhambha Orientalia; 2005. p. 368.

7. Prof. KR Srikanta Murthy. Doshabhediyam. Ashtanga Sangraha of Vagbhata. 9th ed. Varanasi. Chaukhambha Orientalia; 2005. p. 368.

8. Indu Khurana, Arushi Khurana. Textbook of Medical Physiology. Functional Anatomy and general principles of functions of gastrointestinal system. 2nd ed. Gurgaon. Elsevier; 2015. p. 584.

9. Indu Khurana, Arushi Khurana. Textbook of Medical Physiology. Physiological activities in small intestine. 2nd ed. Gurgaon. Elsevier; 2015. p. 631.

10. Indu Khurana, Arushi Khurana. Textbook of Medical Physiology. Functional Anatomy and general principles of functions of gastrointestinal system. 2nd ed. Gurgaon. Elsevier; 2015. p. 574.

11. Indu Khurana, Arushi Khurana. Textbook of Medical Physiology. Functional Anatomy and general principles of functions of gastrointestinal system. 2nd ed. Gurgaon. Elsevier; 2015. p. 584.

\section{Cite this article as:}

Anju Aravind $\mathrm{T}$ et al. Physiological evaluation of Ahara Parinama Kara Bhava: A Review. Int. J. Res. Ayurveda Pharm. 2020;11(3):85-87 http://dx.doi.org/10.7897/2277-4343.110367 